\title{
THE RITUAL OF FIRST INFANT BATHING IN ACEH: An Ethnographic Study in West Labuhan Haji, South Aceh
}

\author{
Abdul Manan \\ The Department of Islamic History and Culture, the Faculty of Adab and Humanities \\ Universitas Islam Negeri Ar-Raniry, Banda Aceh \\ Jl. Ibnu Sina No. 2 Darussalam, Banda Aceh, 23111 \\ e-mail: abdul.manan@ar-raniry.ac.id
}

\begin{abstract}
Childbirth is considered sacred by Acehnese peoples and as such, a newly born baby was introduced to the surrounding world in certain rituals. This is regarded as a re-enactment of the Prophet Muhammad's actions in the seventh century and a continuation of the village norms to preserve the relations of communications and exchanges across generations. The rituals are conducted to honour this process, before and after it, as well as helping mother to heal the physical and mental condition after labouring. This study aimed to describe the ritual of infant bathing practiced by Acehnese people living in the village of Blangporoh, South Aceh. The qualitative approach was applied as the interviews and field observations were due to collect the data. The result indicated that this community still preserved the ritual of infant bathing as a symbol of welcoming the baby as a way to integrate the baby within society. There was also tradition of the animal sacrifice, Akikah, done along the ritual of infant bathing. The author emphasized that both rituals were important within the society as a way to introducing the baby to socio-cultural values since the early childhood.
\end{abstract}

Keywords: rituals, new-born baby, bathing baby, Aceh, Indonesia 


\section{Introduction}

Many first-time mothers, if not all, are thrilled to be pregnant. They believe that their lives will be more exciting and can change for better by giving birth. Harwood, McLean, and Durkin ${ }^{1}$ state that becoming a mother is not always become as a positive experience for all women since they have to adapt to a number of emotional, physical and social changes during the transition for being a mother. Research reveals that a group of women do not cope well with many and new challenges related to motherhood. ${ }^{2}$ For example, the burden of parenthood may cause a variety of negative experiences such as sadness, anxiety and anger. ${ }^{3}$

Apart from that, the process of giving birth is considered as a sacred process by almost all societies in the world. Then, many societies in the world perform certain traditions, ceremonies, and ritual ${ }^{4}$ to honour this process. As people deem that a newborn baby as a new member of community, those traditions, rituals, and ceremonies can be seen as an integrative process. It is in according to Platenkamp ${ }^{5}$ idea that the integrative process in society, in this case is rituals relating to new-born baby, entails the transfer of social attributes from close relatives, neighbours, and more distant bilateral kin to the child.

In this case, traditions, rituals, and ceremonies perceive a social transition of human life. It relates to the change in the life cycle upon the social aspects of an individuals' life. Then, childbirth is a specific moment for women. It signals the major transition of responsibilities: from merely a wife to be a mother. The childbirth is also considered as a dangerous situation for mother and baby, thus, after exceeding this phase, many societies perform certain traditions to celebrate it. Furthermore, they perform those as a way of healing the health. In some cases, the practices even bring healthy benefit for both. As an example, the study by Shetkar et $a l^{6}$ indicated that several practices relating 
to childbirth in India provided healthy benefit. Study by Dennis et al. ${ }^{7}$ also indicated similar benefits.

Besides providing benefits for health, the traditions, rituals, and ceremonies practiced for new-born baby and mother also bring psychological impact. Those serve as anti-anxiety mechanism, which help mother and baby to heal from severe condition of labouring. Such benefit is discussed by Graham, Lobel, and DeLuca $^{8}$ that post-birth rituals practiced by people in South Africa helped soothing mothers and baby.

The community around the world consecrate a new-born baby through various was. As an example, some societies provide specific rations for the baby and mother, as practiced by women in Taiwan. ${ }^{9}$ On the other hand, some communities will give certain traditional herbal remedies, as practiced by people of Beserman in Udmurtia, Russia. ${ }^{10}$ Chand $^{11}$ also noted the rituals of washing the new-born babies within people in Nepal. In short, each community has specific traditions, rituals, and ceremonies to celebrate the significant phase in lifecycle, child birthing, as well as to help mother and new-born baby to heal.

In Aceh, people also consider the process of birthing as a sacred process. Acehnese people even have conducted many traditions since a woman pregnant. Those traditions also exist regarding new-born baby. One of the important rituals practiced by Acehnese people is bathing the infant. This ritual has certain meaning, to amplify the purification of souls, as it also may provide health benefit. Then, this study examined such practice within the Acehnese people living in the village of Blangporoh, South Aceh to describe the process of the ritual, as well as to reveal the socio-cultural meanings beyond it. 


\section{Methodology}

This study was conducted upon the Acehnese people living in the village of Blangporoh, South Aceh. It is done by using qualitative approach to gain the deep understanding toward rituals of bathing the infant. The data were collected during 2017-2018 using field observations and deep interview. Then, the analysis was done on the basis of Miles and Huberman's ${ }^{12}$ qualitative data analysis: data reduction, data display, and drawing conclusion.

\section{Results and Discussion}

The ritual of bathing the infant consists of several rituals, which were held to support the core ritual: bathing the infant. Those are discussed in the following.

\section{Bathing the Baby}

Usually on the seventh day, or some later day, after childbirth, the villagers carry out a series of rituals known as "descending to the water" (in Jamee paturun ka aie, in Acèhnese peutron bak ie) or as akikah (from Arabic 'aqîqah). Like in Gayo, central Aceh $^{13}$, most of the Blangporoh residents use the former term; most town residents, and virtually all modernists use the latter term. These terms refer to different moments in the ritual series in which the child will be positioned within a spatial order. In fact, in some communities, or with small, less developed babies, this ceremony may be put off till after the $44^{\text {th }}$ day after birth.

First, the baby is taken outside the house and held so that its feet touch the earth (Acèhnese peugidong tanoh) and then the baby is shown the sky, the grass, the sand etc. for the first time, representing the overall spatial surroundings where the 
house is situated. Then the baby is bathed in water. This ceremony symbolizes the "descent" of the baby into society and its aim is to introduce the new-born baby into society and into ritual life. It is considered a re-enactment of the Prophet Muhammad's actions in the past and a fulfilment of the village norms to preserve the relationships of communication and exchange across generations. All expenses for this ritual are borne by the baby's father's side.

The ritual must be carefully timed. If the seventh day after birth coincides with the last Wednesday (Acèhnese rabu habéh or huroe na'as) of the month, then one must wait until the fourteenth, the twenty-first or the twenty-eighth day of the baby's life. One also avoids conducting rituals of marriage, circumcision or starting the construction of a house on the last Wednesday of a month. To make the baby "descend" into the society several steps are necessary: Firstly, the midwife (Acèhnese bideun) makes "the baby's mother descend" to the earth in front of her house with a prayer as follows overleaf:

Assalâmualaikum (Peace be onto you). Ayahku langit ibuku bumi (My father is the sky my mother is the earth). Izin lon titi ateh rueng gata (Please let me step on your back). Jino lon gidong singoh lon seuon (Now I step on you later I will carry you on my head). Nepeampon segala dosa (Please forgive all (my) sins)

The midwife teaches the baby's mother to say this prayer as she steps down on the ground (Acèhnese gidong tanoh) for the first time after the delivery because the mother still has hadas besar. ${ }^{14}$ If not then the earth will be angry with the baby's mother. So to avoid the anger of the earth, the midwife says that the do'a must be recited, the same as when the baby's mother has to take a bath on the forty-fourth day after delivery. 
The baby's mother has to say the following prayer (do'a) to the water when she wants to take a bath:

Assalâmualaikum (Peace be onto you). Ibuku ai (My mother is water). Aku muret kepado angkau. (I want to wash my body with you). Aku mandi dalam kalimah lâilâha illallâh (I bath in the words of lâilâha illallâh).

In addition, the same prayer or do'a has to be recited when someone takes a bath after having sexual intercourse. The midwife says, "It is better that bathing after sexual intercourse is performed before the sun rises in the east. If not, the earth will also be angry with her (Acèhnese akan diserapa oleh bumo), and everything she does will not get a "blessing" (Acèhnese beureukat) from it but sin because she still has hadas besar".

Secondly, the midwife followed by the male then the female children carried the baby in a procession to the tomb of Syeikh Muda Waly. The maternal grandmother of the baby brought a tray containing teupông taweue $e^{15}$ and a plate of yellow glutinous rice covered with banana leaves (the banana leaves were heated, so that they could be wrapped around the rice without cracking); the mother also brought some money given to her by her husband; the baby's maternal aunt brought a new towel and clothes for the baby and for Ummi Halimah, the daughter of the Syeikh who was waiting at the well near her father's tomb. This procession was called mambawok ka kubah, "bringing [the baby] to the dome (Indonesian kubah)" of the mosque where the Syeikh's tomb is.

Then, the baby was bathed at the well near the Syeikh's tomb. The daughter of the Syeikh drew water from the well. The midwife poured limejuice (Acèhnese ie bò kruet) ${ }^{16}$ into the water, which was then poured over the baby's body while the mother's sister uttered bismillâh ("in the name of Allâh"). This well water was believed to contain blessings (Jamee barakaik). ${ }^{17}$ 
Historically, the well was a part of the Syeikh's room where he prayed to Allâh.

Having finished bathing, the midwife dries the baby's body and the mother's mother brings it to the Syeikh's tomb. There the baby is "cooled" (Acèhnese dipeusijuek) while being breastfed by its mother. Gifts are given to the baby with wishes for its future well-being. Yellow glutinous rice (Acèhnese $b u$ leukat kuneng) is placed behind the right and left ears while uttering bismillâh slowly ${ }^{18}$ and wishing (Acèhnese meniet, Jamee baniet) that "This glutinous rice is sticky, so please stick [to the baby] the knowledge the baby will acquire later" (Jamee lagu nasi kunyik ${ }^{19}$ ko malakèk-lakèk, bak malakèklah apo yang manyak ko baraja isuk). From a glass on a tray husked and unhusked rice (Jamee padi; Acèhnese padê) are taken and scattered over the baby. Then with a bunch of leaves, rice flour mixed with water (Acèhnese teupông taweue) is sprinkled over it.

Finally, the baby is cradled in a cotton cloth while uttering bismillah over it slowly in a soft voice at the feet of the tombstone. The mother holds one end of the cloth as a swing (Acèhnese ayôn ija), the mother's mother holds the other end, while asking for the well-being (Acèhnese seulawet) of the Prophet Muhammad and his families. Having touched the foot of the tombstone with her right hand the midwife then touches the baby's face with a slow motion so that it will be motivated to do its religious duties as the Syeikh did. The mother then gives some money to the midwife and next the latter puts some money into the baby's hand as a symbol of giving a certificate to the baby containing its parents' name.

In addition, another ritual of peutron bak ie in Blangporoh village that has always been practiced is that if the "descending" baby is female; it will be given to a religious person good at traditional self-defence (Acèhnese meuen silekk) by her father. 
This pious/religious person (Acèhnese ureueng malém) then brings the baby from the house to the earth. The baby is carried on the hip supported by the waist and arm of the religious man, often with the help of a cloth sling. Another pious man shelters the baby with an umbrella. One person splits a coconut over the umbrella with the hope that the baby will later be brave and not afraid of rain (Jamee hujen; Acèhnese hujeun) and thunder (Jamee patuih; Acèhnese geulanteu) and lets the coconut milk drop onto the umbrella. The coconut that has been split is then thrown over the roof to the back of the house with the hope that the baby will later be healthy because all the diseases have been thrown away together with the coconut. In other words, throwing the coconut over the house to the back of the house is a symbol of throwing away all diseases from the baby.

If the "the descending baby" is male, the following ritual is performed; a highly religious learned man who is good at self-defence carries the male baby and supports it on his left waist with his left arm while he holds a sword (Acèhnese peudeueng) with his right hand while wearing traditional Acèhnese clothes (Acèhnese bajè ngon seuleweue adat Acèh). He then cuts seven banana stalks planted by the baby's father in front of the house. He cuts the first banana stalk with one cut, the second banana stalk with two cuts, the third banana stalk with three cuts, the fourth banana stalk with four cuts, the fifth banana stalk with five cuts, the sixth banana stalk with six cuts and the seventh banana stalk with seven cuts. It is said that cutting the banana stalks stands for the braveness of the baby. The baby will become heroic and able to defeat its enemies later on. In this case, the banana stalks are a symbol of an enemy. If the baby does not sleep when the banana stalks are cut, this is a symbol that the baby will become fierce (Acèhnese garang) later. If the baby sleeps while the banana stalks are cut, this is 
a symbol that the baby will be patient (Acèhnese saba) in later life, and if the baby cries when the banana stalks are cut, this is a symbol that the baby will not have a long life (Acèhnese paneuk umu). After bathing the baby, a ram is sacrificed akikah on this occasion.

\section{Akikah}

The sacrifice ritual started about 9 in the morning after the baby had been brought back from being bathed at the well of the Syeikh. As this was a baby girl one akikah = sacrificial ram $^{20}$ was slaughtered: If it had been a baby boy, then there would be two akikah. The slaughtering was done in front of the baby's house. It was said that the akikah (from the Arabic 'aqîa) is about conforming to the historical example of the Prophet Muhammad who slaughtered two sheep for each of his grandsons Hasan and Husén. Its aim is to form a tie between a baby and its parents. Based on the local beliefs, the akikah ram provides a future material benefit on the Day of Judgment (Arabic; al-qiyâma). On judgment day, the baby named as an akikah beneficiary will be able to ride on the animal(s) as a vehicle to the place of judgment bringing the certificate containing its parents' name and will look for its parents.

Before the akikah ram was slaughtered, the animal was first bathed by the baby's father. Soon after its fur was dry, the baby's mother then put hair cream on the wool on the head of the ram and then combed it and sprayed perfume on its body. A mirror was held in front of its face to enable the ram "to see itself; it must see clearly with its eyes".

The father then fed the ram with steamed glutinous rice and cakes. Next, the son of the grandfather's sister of the baby brought a round tray called a dalong or talam with tools for 
"cooling" (Acèhnese peusijuëk) close to the ram. The tools used for the ritual "cooling" 21 of the slaughtered ram were on this round tray, which was closed with a lid (Acèhnese sange). On the round tray, there were several articles:

First, breueh (rice grain) and padé (unhusked rice) were mixed in a basin to form so-called breueh pade. ${ }^{22}$ The breueh padé is then scattered over the ram with a whisk to do the cooling. The breueh padé is said to be symbolic of economy when it is scattered over the ram or over people when cooling is done, as it then becomes food for other living creatures. In addition, it is also said that the breueh padé symbolizes a depth of heart not arrogance and is a sign of dignity or nobility.

Secondly, there were various kinds of grass leaves; several leaves of coarse grass (Acèhnese naleueng sambô; Indonesian rumput saut) with its roots, several leaves of cocor bèbèk (Acèhnese on sisijuek, Indonesian daun sidingin), and several leaves of manèk manòe. ${ }^{23}$ All these leaves were tied in a bunch and placed in a bowl (Acèhnese cawan) with ordinary rice flour (Acèhnese teupông taweue). The function of these three kinds of leaves was to whisk the liquid of ordinary rice flour onto the ram as it was cooled during the ritual of cooling. Each kind of leaf had a different symbolic meaning: The leaves of the sambo grass (Acèhnese on naleueng sambo) together with its roots means a strong life. Its root is very strong, and can grow in any circumstances and any weather. This grass symbolizes a full unshakable commitment (Indonesian istiqamah) and strong faith. It is also a symbol of the "pin of the world" (Acèhnese labang donya). The leaves of cocor bèbèk (Acèhnese on sisijuek) were a symbol of a cooling condition in the household and in society. It was also a symbol of a cool heart, peaceful and not worried. It is said that many families are not happy now because they were not properly cooled (Acèhnese dipesijuek) when they 
got married. ${ }^{24}$ The leaves of manèk manòe are a symbol of fertility. The combination of these three kinds of leaves is symbolic of unity and harmony in a household.

Thirdly, glutinous rice (Acèhnese bu leukat) with coconut stir-fried with palm sugar (Acèhnese $u$ mirah). The glutinous rice is colored yellow with pounded turmeric, so it is called yellow glutinous rice (Acèhnese pulot kuneng or bu leukat kuneng) it is an offering for the ram and a snack for the invited guests on the day of the cooling ceremony day. Glutinous rice (Jamee nasi kunyik or pulot kuneng) is placed behind both ears of the ram as a symbol of peusunténg (it is ritually purified with such a flour mixture). The ram is also fed with it, receiving the same treatment as the bride and groom when they are cooled. Glutinous rice has a meaning of unity because it is sticky and as a symbol of relationships amongst people, as the character of glutinous rice itself is a sticky essence. One says glutinous rice is a symbol of tightening and solidifying the ties amongst the ram, the baby and the parents.

Fourth, teupông taweue, fresh water which has been mixed with ordinary rice flour (Acèhnese teupông breueh) is placed in a bowl together with the above three kinds of leaves. Then the teupong taweue was sprayed on the ram with a bunch of the three leaves to cool it. This means unity and a cold condition. It was clear here that the ram represented the baby. It was a symbol of strength and of a complete life in which people transfer the faculties of perception and self-awareness to the ram even though it was sacrificed at the end.

In the next step, the akikah ram was cooled by the following seven people: the imâm, the baby's father, the baby's mother, the baby's maternal grandmother, the baby's maternal grandfather, the baby's maternal great grandmother, and the baby's paternal grandfather. This was a prime number because Allâh is Special. 
There is only one number seven and Allah likes something unique, therefore people choose what Allâh likes, says one teungku. ${ }^{25}$ Others say the healing number should be odd and prime (i.e. 3 or 5 or 7 or 11 or 13 or 17 or 19). Next, the akikah ram was brought by the baby's paternal uncle, i.e. the brother of the father of the baby to a hole dug by the baby's maternal grandfather in the front house yard. There, it was given to the baby. At the same time, another tray containing articles wrapped with a white cloth called ayapan was prepared by the mother's younger sister. ${ }^{26}$ This was then brought near to the hole by the baby's maternal great grandmother. The ayapan contained the following articles: a comb, soap, a toothbrush, a mirror, a knife, face powder, shampoo, perfume, an umbrella, and tooth paste as if they were preparing the baby for the afterlife although these articles are not complete. It is believed that Allāh will later add what is incomplete. In addition, all these things were wrapped in a white cloth as a holy and sincere symbol, for the baby from the parents. Rp10.000, 00 was placed at each end of the white cloth as if to pay for sewing the baby's clothes in the afterlife. In other words, placing money at each end of the white cloth was to complete it where it is incomplete because the slaughtered ram must be perfect.

Now the akikah ram was taken near to the hole. The baby's father gave the imâm a sharp knife while his left hand held tight the rope around the ram's neck while uttering "this is the akikah ram for my daughter, Nadia, for example, (Jamee iko kambiang akikah untuk anak ambo Nadia). The imâm then answered, "I have accepted it" (Jamee alah ambo tarimo). Meanwhile, the baby's paternal uncle grasped the feet of the ram strongly. The imâm said bismillâh (in the name of Allâh, the merciful, the compassionate) and recited the syahadat, the confession of faith (I attest that there is no deity but Allâh and that Muhammad 
is His messenger) and dedicated the ram as follows, "This is the akikah ram for Jamlis' daughter, Nadia” (Jamee iko kambiang akikah untuk anak padusi Jamlis, Nadia) followed by uttering bismillâh "in the name of Allâh" once and Allâhu akbar "Allâh is great" three times. At the completion of the dedication, he cut the akikah ram's throat. A ram is similarly sacrificed at the festival of the sacrifice day (Arabic: $\hat{1} d$ al-Adhâ).

As the akikah ram was being slaughtered, the white cloth was placed over it. The white cloth was said to function as an umbrella for the baby in the afterlife. The white cloth was held over the akikah ram by the following people; the front right of the white cloth was held by the baby's mother; the front left of the white cloth was held by the baby's father; the back right of the cloth was held by the baby's maternal great grandmother. The back left of the white cloth was held by the baby's maternal grandmother.

After the akikah ram had been sacrificed, the white cloth was rolled up and put back on the tray. The white cloth with the articles called ayapan was given to the imâm by the baby's maternal grandfather with the following words: "this ayapan is for teungku [imâm]" (Jamee Iko ayapan pulang ka tuangku) and he answered, "I have received this ayapan" (Jamee alah ambo tarimo ayapan ko). The contents of the ayapan were later divided up amongst four people, viz: the imâm, the preacher, the meuzin [the person who calls people for prayers (Acèhnese teungku bileu)], and the caretaker of the mosque (teungku khadam). At the time the ram was sacrificed, the head of the village only monitors the process of the sacrifice. As the guests come, he is the person who welcomes the guests to eat the food provided on behalf of the family on the akikah day; meanwhile the midwife sits in the room of the baby's mother to "receive" and 
to accompany the female guests coming to the akikah ritual on that day.

Some say that the akikah ram is not for the baby but for the poor, only its religious merit is for the baby. The religious merit in the afterlife will become a vehicle that helps the baby to look for its parents. The front right leg of the slaughtered ram was given to the midwife. The same thing is done in Susoh, another aneuk jamee speaking area. ${ }^{27}$ I asked the baby's uncle's father's brother, why was the front right leg of the sacrificed ram given to the midwife? He answered, "Here in Blangporoh this tradition is an adat otherwise the akikah ram is not perfect". Perfection here means that the "horse" that the baby will ride in the afterlife will only have three legs. This, it is said, will happen because it was not given to the midwife when the akikah was performed on earth. Others say that the front right leg of the akikah ram is the midwife's right because she has helped the baby and the baby's mother and washed them both at the delivery.

Besides the front right leg of the akikah ram, the midwife is also given complete spices for cooking called aweuh lengkap ("complete coriander") by the baby's maternal grandmother. Aweuh lengkap consists of one kilogram of rice, one coconut, lemons, salt, onion, garlic, ginger, coriander, saffron, pepper, galingal, fennel, stern-anis, fried grated coconut, bay leaves, cardamom, coconut oil, lemon grass, several lime leaves, cattapa, candlenuts, and dried carambolas for cooking the front right leg of the akikah ram she was given. It was said that giving aweuh lengkap to the midwife on the day of akikah was a tradition in Blangporoh village. ${ }^{28}$ 


\section{Conclusion}

In this article, we have looked at the ritual of peutron bak ie "bathing" a newborn baby in Blangporoh village: We have seen it essentially as a ritual in action. Through this ritual, a new baby was introduced to the world around it and into Blangporoh family life. This was considered a re-enactment of the Prophet Muhammad's actions in the seventh century and a continuation of the village norms to preserve the relations of communications and exchanges across generations. The baby was taken outside the house and placed with its feet on the earth to let it see the sky for the first time, representing the overall spatial surroundings in which the house is situated. The baby was bathed with well water, which it is believed contains "blessings" originating from the prayers of the former Syeikh.

Gifts were, after that, given to the baby carrying wishes for its well-being. Yellow glutinous rice was placed behind the right and the left ears representing knowledge that the baby will acquire later", with a bundle of specially chosen leaves, rice flour mixed with water was sprinkled over the baby. The baby was cradled in a cotton cloth at the feet of the Syeikh's tombstone. The mother held one end of the cloth like a hammock swing, the mother's mother the other end, while asking for well-being from the prophet and his families. After having touched the foot of the tombstone, the Syeikh's daughter touched the baby's face so that it will be motivated "to do her religious duties as the Syeikh did". The mother gave some money to the midwife and she in turn put some money in the baby's hand as a "sign that the baby has its parents' name". This ceremony symbolised the "descent" of the baby into society. From this moment on, the new baby is given social recognition and its ritual persona is established within the community and in relation to the founding ancestor of the village, the Syeikh. 
The ritual of peutron bai ie is regarded as a momentous epoch in the life of the baby when it first encounters "mother" earth. The baby is not allowed to lie or to sit upon the ground until such contact has been duly prepared by a number of rituals, of which a religious feast forms an important part for the earth, which contains so much "blessing", and holds so much that is evil. This ritual can be described as an "initiatory ritual”. It introduces the child to the natural world and to important facets of everyday life and at once evokes and implements a relationship of continuing well-being between the Blangporoh social life and the village's founding ancestor.

Following this ritual bathing, the sacrifice (akikah) for "redeeming" the child for Allâh was performed "as one would redeem mortgaged land". The parents are in debt to Allâh for a child and this sacrifice cancelled out that debt. It also created a tie between the parents and the child. The akikah ram provided a future gift for the baby. On Judgment Day, the baby named as an akikah beneficiary will be able to ride on the sacrificial animal as a vehicle to the place of judgment bringing the certificate containing her/his parent's name, and will be able to look for its parents.

\section{References}

Brown, R. "Taboo," in William A. Lessa \& Evon Z. Vogt (eds.). Reader in Comparative Religion: An Anthropological Approach. New York: Harper Collins Publishers, 1979.

Chand, S. B. "Cultural Beliefs and Traditional Rituals about Child Birth Practice in Rural, Nepal," in MedCrave: Step into the World and Research, Vol. 5, No. 1, 2016.

Cowan CP., \& Cowan PA. "Interventions to Ease the Transition to Parenthood: Why They are Needed and What They Can 
Do," in Family Relations: Interdisciplinary Journal of Applied Family Science, Vol. 44, No. 4, 1995.

Dennis, C.-L., Fung K., Grigoriadis S., Robinson G. E., Romans $S$ \& Ross L. "Traditional Postpartum Practices and Rituals: A Qualitative Systematic Review," in Women's Health, Vol. 3, No. 4, 2007.

Graham JE., Lobel M \& DeLuca RS. "Anger after Childbirth: An Overlooked Reaction to Postpartum Stressors," in Psychology of Women Quarterly: Society for Life, Vol. 26, No. 3, 2002.

Greg, D. "Traditional Acehnese House," in J. Maxwell (ed.), The Malay Islamic World of Sumatera. Melbourne: Monash University, 1982.

Harwood K., McLean N. \& Durkin K. "First-time Mothers' Expectations of Parenthood: What Happens When Optimistic Expectations are not Matched by Later Experiences?," in Dev Psychol, Vol. 43. No. 1, 2007.

Huang, Y. C \& N. J. Mathers. "A Comparative Study of Traditional Postpartum Practices and Rituals in the UK and Taiwan," in Diversity \& Equality in Health and Care, Vol. 7, No. 4, 2010.

LAKA. Pedoman Umum Adat Aceh I. Banda Aceh: LAKA Provinsi Daerah Istimewa Aceh, 1990.

Manan, Abdul. "The Ritual of Khanduri Bungong Kayee: An Ethnographic Study in West Labuhan Haji, South Aceh," in Anthropology Indonesia Indonesian Journal of Social and Cultural Anthropology. Vol. 34 No. 2, 2013.

Manan, Abdul. The Ritual Calendar of South Aceh, Indonesia. WWU Muenster: Wissenschaftlische Schiften, 2015.

Manan, Abdul. "The Ritual of Khanduri Laot in Lowland Aceh: An Ethnographic Study in South, South West and West Aceh," in MIQOT: Jurnal Ilmu-ilmu Keislaman, Vol. XL No. 2, 2016. 
Manan, Abdul. "Ritual Berburu Batu Geok pada Masyarakat di Pergunungan Singgah Mata: Penelitian Etnografi di Kecamatang Beutong Ateuh, Nagan Raya-Aceh," in Proceeding: International Conference on Education, Islamic Studies and Social Sciences Research (ICEISR I). Banda Aceh: Universitas Syiah Kuala, 2016.

Manan, Abdul. "The Ritual of Hunting Deer within the People of Kluet in South Aceh, Indonesia," in Proceeding: International Conference on Education, Islamic Studies and Social Sciences Research (ICEISR II). Bandung: Universitas Mercu Buana, 2017.

Milles, M. B \& A. M. Huberman. An Expanded Sourcebook: Qualitative Data Analysis. 2nd Edition. London: SAGE Publications, 1994.

Platenkamp, J. D. M. "Lao Ritual of Birth and Socialisation," in presented at The Status of The Stranger, Paris, 2016.

Popova, Y. "Traditional Childcare and Treatment of Children's Diseases among the Besermian," in Folklore: Electronic Journal of Folklore, Vol. 30, 2005.

Shetkar, Reshma M., Alex H., \& H. R. Nagendra. "Reason for Health Benefits of Deep Meditation: Self Organized Criticality Restores Regulation to Optimal," in Eur J Pharm Med $R$ (EJPMR), Vol. 3, No. 5, 2016.

Thorp SR., Krause EDL, Cukrowicz KCL \& Lynch TR. "Postpartum Partner Support, Demand-Withdraw Communication and Maternal Stress," in Psychology of Women Quarterly: Society for Life, Vol. 28, 2004. 


\section{Endnotes:}

${ }^{1}$ Harwood K., McLean N \& Durkin K. "First-time Mothers' Expectations of Parenthood: What Happens When Optimistic Expectations are not Matched by Later Experiences?," in Dev Psychol, Vol. 43. No. 1, 2007, pp. 1-2.

${ }^{2}$ Cowan CP., \& Cowan PA, "Interventions to Ease the Transition to Parenthood: Why They are Needed and What They Can Do," in Family Relations: Interdisciplinary Journal of Applied Family Science, Vol. 44, No. 4, 1995, pp. 412-423.

${ }^{3}$ Thorp SR., Krause ED, Cukrowicz KC \& Lynch TR, "Postpartum Partner Support, Demand-Withdraw Communication and Maternal Stress," in Psychology of Women Quarterly: Society for Life, Vol. 28, 2004, pp. 362-369.

${ }^{4}$ Religious ceremonies consisting of a series of action performed according to prescribed order, are the core of the social identity of all communities (Manan, 2015: 2), for example; the Ritual of Khanduri Laot in Lowland Aceh (Manan, 2016), The Ritual of Khanduri Bungong Kayee in West Labuhan Haji, South Aceh (Manan, 2013), The Ritual of Hunting Deer within the People of Kluet in South Aceh, Indonesia (2017), and Ritual Berburu Bato Geok pada Masyarakat di Pergunungan Singgah Mata: Penelitian Etnografi di Kecamatang Beutong Ateuh, Nagan RayaAceh (2016).

${ }^{5}$ J. D. M. Platenkamp, "Lao Ritual of Birth and Socialisation," presented at The Status of The Stranger, Paris, 2016.

${ }^{6}$ Reshma M. Shetkar, H. Alex \& H. R. Nagendra, "Reason for Health Benefits of Deep Meditation: Self Organized Criticality Restores Regulation to Optimal," in Eur J Pharm Med R (EJPMR), Vol. 3, No. 5, 2016, pp. 435-41.

${ }^{7}$ C.L. Dennis, K. Fung, S. Grigoriadis, G.E. Robinson, Sarah Romans, \& L. Ross, "Traditional Postpartum Practices and Rituals: A Qualitative Systematic Review," in Women's Health, Vol. 3, No. 4, 2007, pp. 487-502.

${ }^{8}$ J.E. Graham, M. Lobel \& R.S. DeLuca, "Anger after Childbirth: An Overlooked Reaction to Postpartum Stressors," in Psychology of Women Quarterly: Society for Life, Vol. 26, No. 3, 2002, pp. 222-233.

${ }^{9}$ Y.C. Huang \& N. J. Mathers, "A comparative study of traditional postpartum practices and rituals in the UK and Taiwan," in Diversity \& Equality in Health and Care, Vol. 7, No. 4, 2010.

${ }^{10}$ Y. Popova, "Traditional Childcare and Treatment of Children's Diseases among the Besermian,” in Folklore: Electronic Journal of Folklore, Vol. 30, 2005, pp. 65-96.

${ }^{11}$ S. B. Chand, "Cultural Beliefs and Traditional Rituals about Child Birth Practice in Rural, Nepal," in MedCrave: Step into the World and Research, Vol. 5, No. 1, 2016.

${ }^{12}$ M.B. Milles \& A.M. Huberman, An Expanded Sourcebook: Qualitative Data Analysis, 2nd Edition (London: SAGE Publications, 1994). 
${ }^{13}$ R. Brown, "Taboo," in William A. Lessa \& Evon Z. Vogt (eds.), Reader in Comparative Religion: An Anthropological Approach (New York: Harper Collins Publishers, 1979), pp. 46-56.

${ }^{14}$ Women are obliged to take a bath (Acèhnese manoe wajib) after menstruation, childbirth or confinement (Arabic wiladah), and after having sexual intercourse. While for the men, they are obliged to take a bath if their sperm leaves them and after just having had sexual intercourse. When women and/or men fit one of these categories, they are called berhadas besar. These ideas are based on Islamic jurisprudence.

${ }^{15}$ Sometimes one hears the villagers say teupông tabeu (tasteless flour) instead of teupông taweue. Teupông taweue is water mixed with ordinary rice flour (Acèhnese teupông breueh bit) and the leaves of cocor bèbèk (Acèhnese on sisijuek, Indonesian daun sidingin) symbolize a cold condition. A stalk of coarse grass with its root (Acèhnese naleueng sambô; Indonesian rumput saut) symbolizes a strong and sturdy life. It prevents problems, and medicinal leaves (Acèhnese on sitawa; Indonesian daun penawar) are said to prevent fever. The leaves of these plants are tied in a bunch used as a whisk to spray the water of teupông taweue (cooling ceremony) onto the baby's body.

${ }^{16}$ One is bathed with limejuice (Acehnese ie bòh kruet) at least three times in his or her life: first, as a baby when bathed for the first time after birth; second, when the baby descends into the "water" (Acèhnese peutron u ie; Jamee paturun ka aie), and third, when one dies, and it is used as a shampoo.

${ }^{17}$ Baraka (Jamee barakaik, Acèhnese beurekat) is a special blessing assigned by Allâh to certain individuals but the word baraka here means that the baby will not be easily attacked by disease.

${ }^{18}$ If the cooling ceremony is performed for adults, the glutinous rice is directly fed into their mouths after it is cool enough to eat.

${ }^{19}$ Sometimes the villagers say sipuluik instead of nasi kunyik for glutinous rice.

${ }^{20}$ For the male baby two rams or sheep are recommended to be sacrificed. If the akikah's slaughtering is not possible on the seventh day, it may be performed at some later date-even when the child is quite grown up. Blangporoh people consider akikah to be recommended (sunat) rather than required (wâjib). Akikah is not mentioned in the Qur'ân, but in Hadîth. Many families hold the khanduri without killing a ram. For this reason most people in Blangporoh refer to the khanduri as a khanduri peutron bak ie than as akikah.

21 "Cooling" rituals have a very strong place in traditional Acehnese adat. Cooling is divided into two groups; First, cooling in human life: cooling as the bridegroom leaves his house; cooling when the bride's side receives the bridegroom; cooling before the bride-to-be takes a bath; cooling on the day of cutting the bride-tobe's hair; cooling on the day of applying henna; cooling before the bridal couple sit on the bridal dais; cooling of a boy before he is circumcised; cooling of someone after having a fight; cooling before one goes on and after one returns from a pilgrimage; cooling just before a person leaves home to make his/her way in life and cooling after 
getting a new position. Second, "cooling rituals" which are not part of a human's life, namely: cooling of the rice seeds before planting them; cooling of the site before one starts to build a house; cooling of the sacrificial or aqiqa ram; cooling of a new house before one moves in; cooling of a new car, truck or horse as a means of transportation).

${ }^{22}$ Sometimes people use padé and breh kunyèt (rice is yellow in colour because it is mixed with pounded turmeric). Rice, which is not yet pounded, is called padé.

${ }^{23}$ For the complete leaves used for teupông taweue, see wriings on khanduri bungong kayèe.

${ }^{24}$ One strongly emphasizes that cooling (Acèhnese peusijuek) ceremonies are very important in life.

${ }^{25}$ The traditional stairs in an Acèhnese house also have an odd number. This is based on the idea that when exiting a house one will put his/her right foot on the first step and will put his/her left foot on the last step. The step is therefore designed so that the right foot is to reach the ground, not the left one. This is based on the belief that luck will accompany the person and make his/her journey safe.

${ }^{26}$ The baby's mother's younger sister was working in the kitchen meanwhile the baby's mother and another younger brother helped carry the trays containing coffee and tea for the invited guests.

${ }^{27}$ In Susoh, another aneuk jamee speaking area, the old men in the village remind the baby's father on the third or fifth day after the child's birth as follows: "hai buyung, anak wa ang alah lahi hari katujuh wa ang akikahkan sabalah paho untuk makbiden" meaning "hi buyung (term addressed for baby's father), your child is already born, on the seventh day, you must sacrifice a ram for it and one leg of the ram is for the midwife (Acèhnese bideun)".

${ }^{28}$ Unlike the akikah ram in Blangporoh, The akikah ram in Pawoh village, Susoh, Abdya or Southwest Acèh, is divided into seven portions: one portion is given to the wali karong (wali adat), another portion is given to the wali meuketam (wali hukom), and the other five portions are divided amongst the poor neighbours and the orphans. 